\title{
On the fasciculus longitudinalis medialis in the brain of Mugil cephalus*
}

\author{
By \\ Tamura, J., Yashiki, K., Takata, K. and Yamao, T. \\ Department of Anatomy, Hiroshima University School of Medicine, Kure, Japan
}

(Director: Prof. N. Suzuki)

With 10 figures

\section{Introduction}

In the piscian brain, the fasciculus longitudinalis medialis is a complicated system of fibers, chiefly descending, connecting the deeper areas of gray between the mesencephalon and the spinal cord. Furthermore, the fibers from the brachium conjunctivum, the several tegmental fascicles, the tractus cerebello-et octavo-motorius anterior adjoin to this fasciculus (Goldstein, '05, Sheldon, '12, Burr, '28, Ariëns Kappers, '21, '36 and others). Some of the descending fibers which originate in the telencephalon may come into the synaptic relation with cells of origin of the medial longitudinal fasciculus (Sheldon, '12), through which bundle impulses from the olfactory centres of the telencephalon are transmitted to the efferent centres of the medulla oblongata and the spinal cord (Ariëns Kappers, '36). The nucleus of the fasciculus longitudinalis medinalis which lies in the ventricular eminence of the peduncle comes into synaptic relation with cells of the oculomotor nucleus (Beccari, '12, '31), the giant fibers of Mauthner's cell (Bartelmetz, '15) and also with large cells in the region ventral and ventrolateral to the medial longitudinal fasciculus (Franz, '12, Holmgren, '20, Burr, '28).

*) This investigation was supported in part by a grant for scientific reseach from the Department of Educatian of the Japanese Government.

- N. Suzuki- 
Nevertheless, the relation of the nucleus of the fasciculus longitudinalis medialis with other efferent centres of the medulla oblongata and the synapsis of the fiber constitution of this fasciculus require further investigation.

\section{Material and Methods}

For this purpose, the adult brains of Mugil cephalus were employed. After completely fixed with $20 \%$ neutral formalin, they are cut transversally, sagittally and horizontally (ca. $15 \mu$ in thickness). These serial preparations were treated with Pal-carmine deying, Sugamo's method, Bielschowsky's pyridin silver impregnation.

\section{Findings}

In horizontal series, the nucleus of the medial longitudinal fasciculus $^{1}$ is present rostral to the nucleus oculomotrius along the ventricular eminence and the latter nucleus receives collaterals and terminal fibers from the medial longitudinal fasciculus (Fig. 1). A few of fibers from this fasciculus run ventromedially to decussate at the midline, while the majority of its fibers pass through the oculomotor nucleus to elongate caudalward.

Tracing more ventrally, the fibers from the commissura posterior adjoin to this fasciculus. The reticular cells near the oculomotor nucleus which has been termed the nucleus interstitialis may have a synaptic relation with this fasciculus (Fig. 2) Burr ('28) did find a midline cell group extending from the medial longitudinal fasciculus to the ventral surface of the brain. In this section, numerous fine fibers from the tuber posterior enter this fasciculus. Tracing more ventrally, the well-myelinated fibers of the tractus praetecto-spinalis elongate spinalward to join this fasciculus after crossed at the midline (Fig. 3).

Tracing more ventrally, the fasciculus longitudinalis medialis receives numerous neuraxes of the reticular cells which suggested by Burr ('28) as a "generalized ancester of the olive". The region of termination of the neuraxes of the small cells of the more frontal

1) The nucleus of the medial longitudinal fasciculus may be homogenous to the nucleus of Darkschewitsch, after called the nucleus of the posterior commissure in the mammalian brain (cf. Ranson, '49, p. 185). 
reticular groups is not definitely ascertained as indicated by Ariëns Kappers ('36). It has been said that the nucleus reticularis mesencephali ${ }^{1)}$ contributes fibers to the posterior commissure. This matter, however, requires further investigation.

In sagittal series, cells of the nucleus of fasciculus longitudinalis medialis lies in front of the oculomotor nucleus and are densely arranged being surrounded with fiber neuropil (Fig. 4). In this section, a few of fibers derived from the commissura posterior stream into the neuropil of this commissure. Tracing more medially, the majority of this fasciculus extend caudally along the ventricular margin passing through the oculomotor nucleus and the fibers of the latter nucleus adjoin to this fasciculus. The oculomotor nucleus ${ }^{2}$ especially the dorsolateral nucleus of oculomotor also receives collaterals and terminal fibers from the medial longitudinal fasciculus, apparently arising from nuclei of the vestibular nerves, as indicated by Beccari ('31) (Fig. 5). A few of fibers from the nucleus trochlearis also run into this fasciculus (Fig. 6).

The ascending fibers arose from the ventricular nuclei terminate in the dorsolateral part of the oculomotor nucleus (Fig. 7), the abducens nucleus (Fig. 8) and feebly in the trochlear nucleus (Fig. 9). The latter nucleus is situated further caudal to the oculomotor nucleus in the ventricular eminence, having an indirect relation with this fasciculus (Fig. 10), contrary to the description of Ariëns Kappers, Huber and Crosby ('36) in cyclostomes.

In the entire length of the fasciculus longitudinalis medialis, the synaptic relation with this fasciculus and the nucleus reticularis mesencephali and the large and small reticular cells of the brain stem and the medulla oblongata can be estimated. In this specimens, however, the Mauthner's cells are ill-developed, so that it is scarcely

1) Jansen ('30) found that in Myxine the laterodorsal neurons of the nucleus reticularis mesencephali send large dendrites in a dorsal direction to intermingle with the posterior commissure fibers (cf. Ariëne Kappers, Huber and Crosby ' 36 , p. 648).

2) Cf. Ariëns Kappers, Huber and Crosby ('36, p. 526): The oculomotor nuclear gray may be divided into three nuclear groups (Tretjakoff, '09) in Ammocoetes a ventral nucleus giving rise to crossed fibers, a dorsal and lateral nucleus sending homolateral fibers.

3) Cf. Ariëns Kappers, Huber and Crosby ('36, p. 627): Both the trochlear and the oculomotor nuclei lie in very close relation to the medial longitudinal fasciculus, through which they are interrelated with other efferent nuclei of the brain stem (particularly with the nucleus of the abducens nerve) and with the vestibular centres. 
distinguished from large reticular cells of the medulla oblongata.

\section{Concluding remarks}

In general, the fasciculus longitudinalis medialis in the piscian brain is a remarkable compact bundle of fibers extending from a point near the rostral border of the mesencephalon to the rostral segments of the spinal cord, where it is continuous with the anterior fasciculus proprius as shown in mammalian brains and physiologically, this fasciculus is especially concerned with the reflex control of the movement of the body and eye musculatures. In its entire course, this fasciculus has respectively a synaptic relation with the oculomotor, trochlear and the abducens nuclei. Furthermore, a large proportion of its fibers are derived from the vestibular nuclei. In cephalad course of this fasciculus, the tractus praetecto-spinalis, the commissura posterior and the tractus vestibulo-cerebellaris stream into this fasciculus.

Furthermore, the fibers derived from the tegmental fascicles loosely join to the medial longitudinal fasciculus. The tractus cerebellotegmentalis or brachium conjunctivum anterius which is regarded as a special derivative of the cerebello-motorius system partly terminate in the oculomotor nucleus, but the relation with this fasciculus is not well accomplished. The synaptic relation with the fasciculus longitudinalis medialis and the descending fibers originated in the telencephalon can scarcely be ascertained. The neuraxes of the nucleus interstitialis, the large and small cells of the nucleus reticularis respectively have a synaptic relation with this fasciculus. But it is uncertain whether the neuraxes of the rudiment sense and bipolar cells of the pineal gland terminate in the nucleus of origin of the medial longitudinal fasciculus or not as shown by Ariëns Kappers, Huber and Crosby ('36).

\section{References}

Ariëns Kappers, C. U. 1939 Anatomie comparee des connexions centrales du huitieme nerf dans la serie des vertebres. Rapport au Congres de la Societas OtoRhino-Laryngologica. Latina, Utrecht, 1939.

Ariëns Kappers, C.U., Huber, G.C. and Crosby, E.C. 1936 The comparative anatomy of the nervous system of vertebrates, including man. MacMillan Company, New York.

Bartelmetz, G. W. 1915 Mauthner's cell and the nucleus motorius tegmenti. J. Comp. Neur., vol. 25. 
Beccari, 1934 Contributi alla migliose conoscernza della terminazioni centrali del nervo acustico mei Pesci. Psych. en Neurol. Bladen, 1934.

Burr, H.S. 1928 The central nervous system of Orthagoniscus mola. J. Comp. Neur., vol. 45 .

Franz, V. 1912 Beiträge zur Kenntnis des Mittelhirns und Zwischenhirns der Knochenfische. Folia neurobiol., Bd. 6.

Goldstein, K. 1905 Untersuchungen über das Vorderhirn und Zwischenhirn einiger Knochenfische, nebst einigen Beiträgen über Mittelhirn und Kleinhirn derselben. Arch. f. mikr-Anat. und Entw.-Ges., Bd. 66.

Herrick, C.J. 1948 The brain of the tiger salamander, Amblystoma tigrinum. The University of Chicago Press, Chicago, Illinois.

Holmgren, N. 1920 Zur Anatomie und Histologie des Vorder- und Zwischenhirns der Knochenfische. Acta zool., 1920.

Jansen, J. 1915 The brain of Myxine glutinosa. J. Comp. Neur., vol. 49.

Kuntz, A. 1950 A text-book of neuro-anatomy. Lea \& Febiger, Philadelphia.

Ranson, S. W. 1948 The anatomy of the nervous system, its development and function. S. W. B. Sanders Company, Philadelphia \& London.

Strong, O.S. and Elwyn, A. 1953 Human neuroanatomy. The Williams \& Wilkins Co. Baltimore.

Suzuki, N. 1932 On the nerve fiber systems of the lobi inferiores in the brain of Salmonidae. Annual Report of the Work, Sendai, Japan, no. 8 (The Saito Gratitude Foundation).

- 1935 On the commissura transversa Halleri in Cyprinoids. Folia Anatomica Japonica. Bd. XII, H. I.

\section{Abbreviation for all figures}

ascend. $f$

ascending fibers

cb....... cerebellum

com. ans.

commissura ansulata

com. $p$.

commissura posterior

fasc. long. 1 .

faseiculus longitudinalis lateralis

fasc. long. $m$

fasciculus longitudinalis medialis

fasc. retrofi.

fasciculus retroflexus

interped

interpeduncle

nuc. d. 1. nuc. III

nucleus dorso-lateralis of nucleus oculomotorius

nuc. fasc. long. $\mathrm{m}$

nucleus of fasciculus longitudinalis medialis

nuc. interst

nucleus interstitialis

nuc. III.

nucleus oculomotorius

nuc. IV.

nucleus trochlearis

nuc. VI.

nucleus abducens

r. $1 \mathrm{~V}$.

root of trochlear nerve

reticl. c

reticular cells

tr. cb. teg

tractus cerebello-tegmentalis

tr. t. cb.

tractus tecto-cerebellaris

tr. praet. sp tractus praetecto-spinalis

valv, cb valvula cerebelli

vel. $\mathrm{m}$. a velum medullare anterius

ventr. ventriculum

vest. lob vestibular lobe 
Plate I

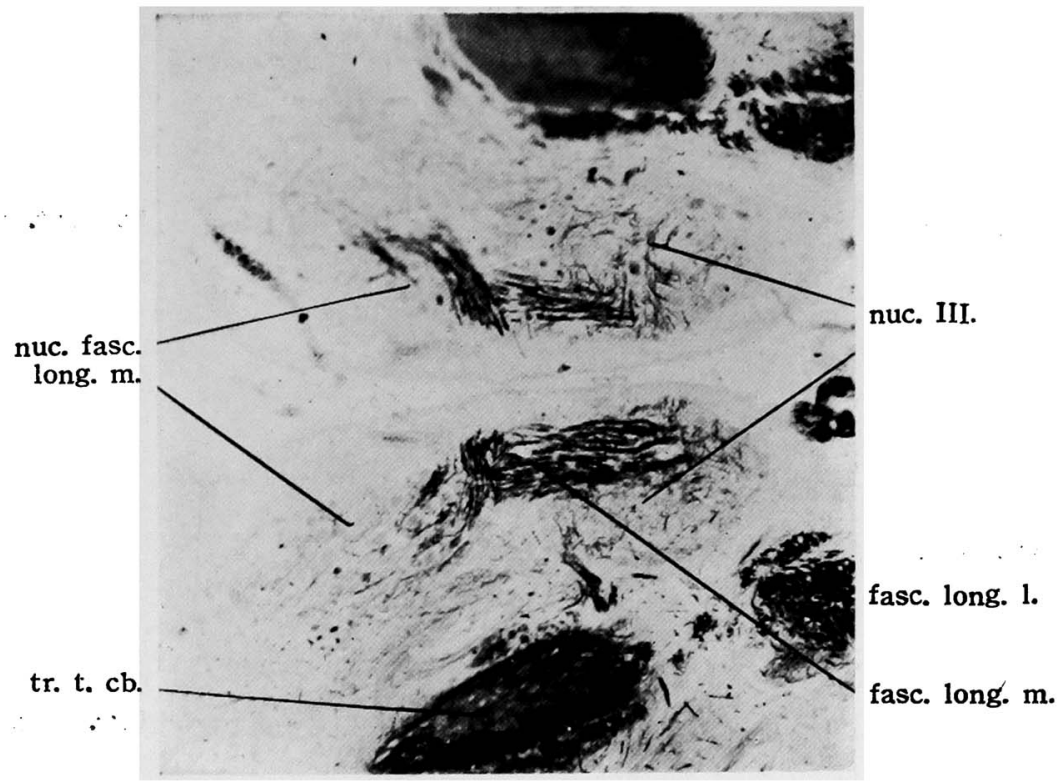

Fig. 1. Horizontal section passing through the nucleus of fasciculus longitudinalis medialis (Pal-carmine stained).

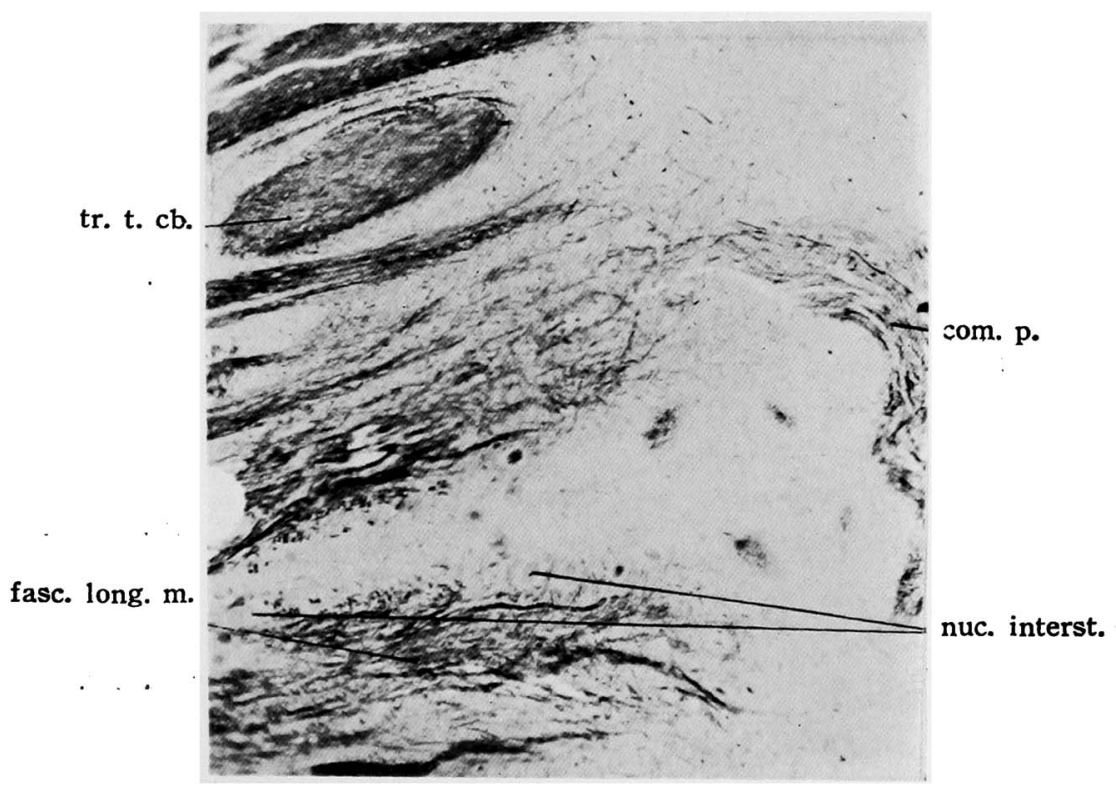

Fig. 2. Horizontal section passing through the commissura posterior (Sugamo's method).

J. Tamura, K. Yashiki, K. Takata, and T. Yamao. 
Plate II

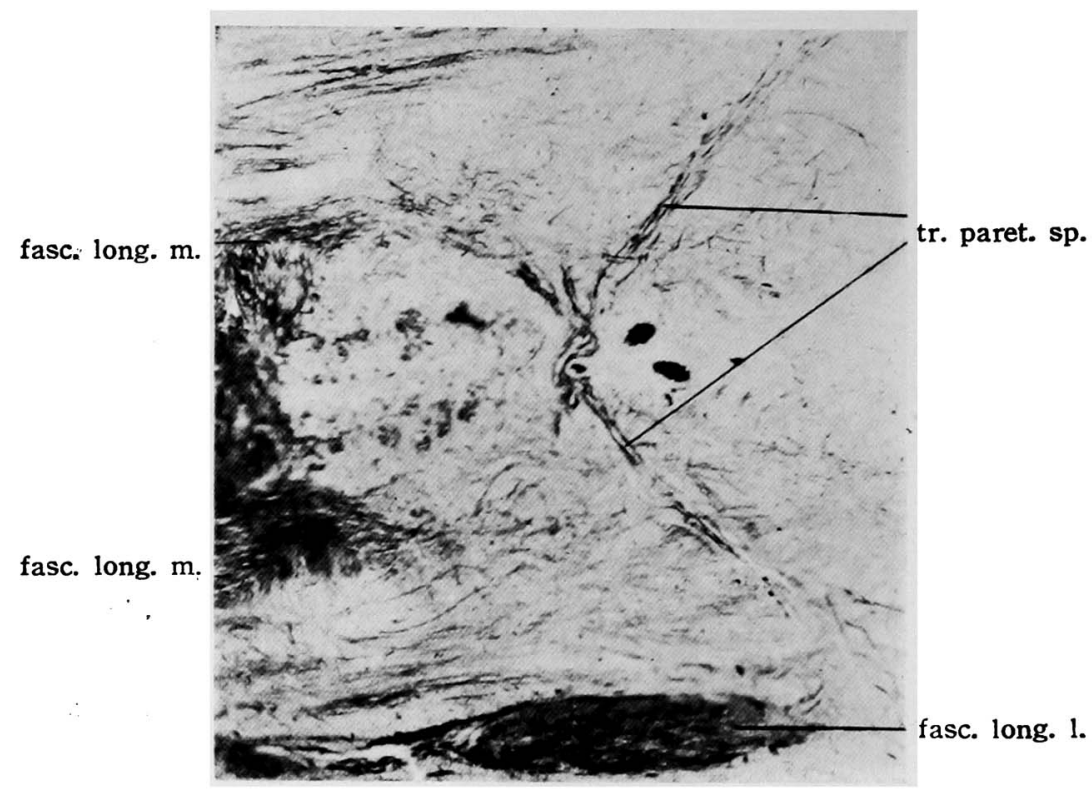

Fig. 3. Horizontal section passing through the decussation of fibers of the tractus praetecto-spinalis (Sugamo's method).

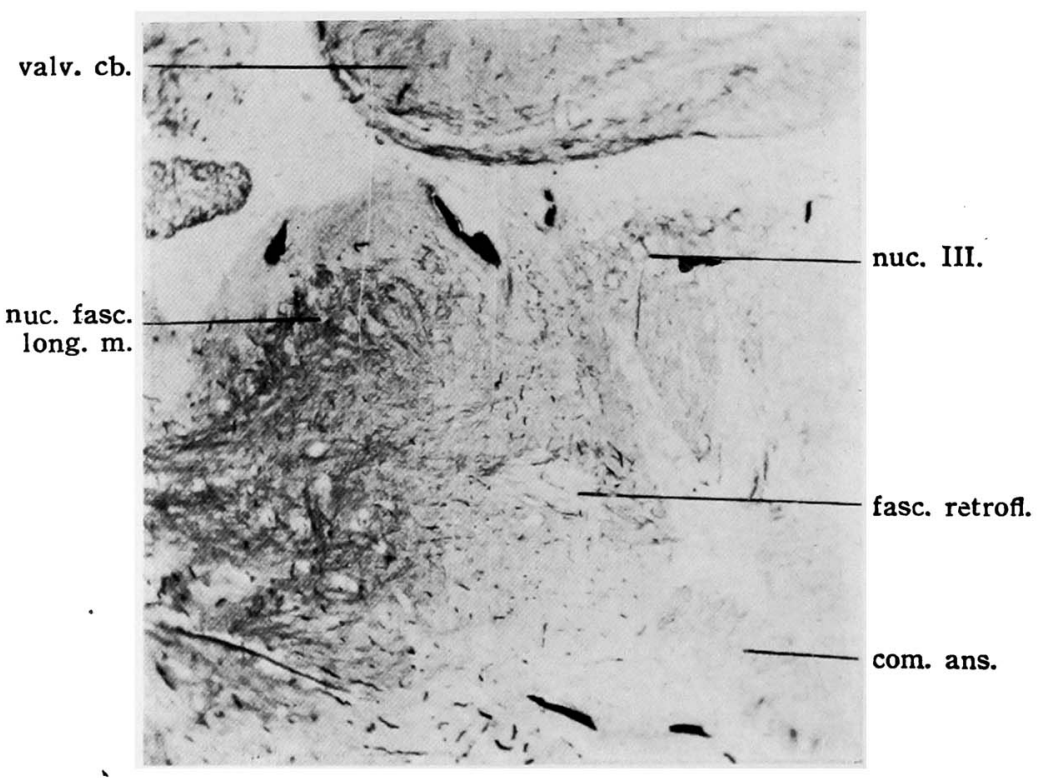

Fig. 4. Sagittal section passing through the nucleus of fasciculus longitudinalis medialis and the nucleus ozulomotorius (Bielschowsky's pyridin silver method).

J. Tamura, K. Yashiki, K. Takata, and T. Yamao. 


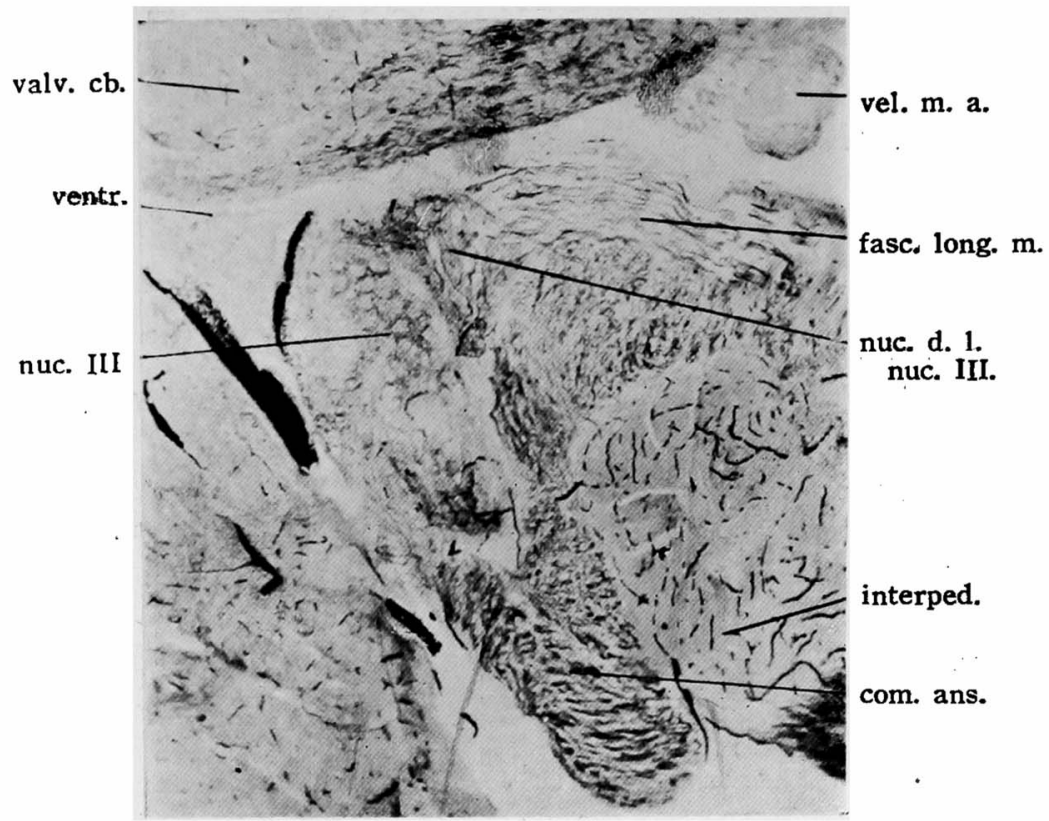

Fig. 5. Sagittal section passing throuugh the nucleus oculomotorius (Bielschowsky's pyridin silver method).

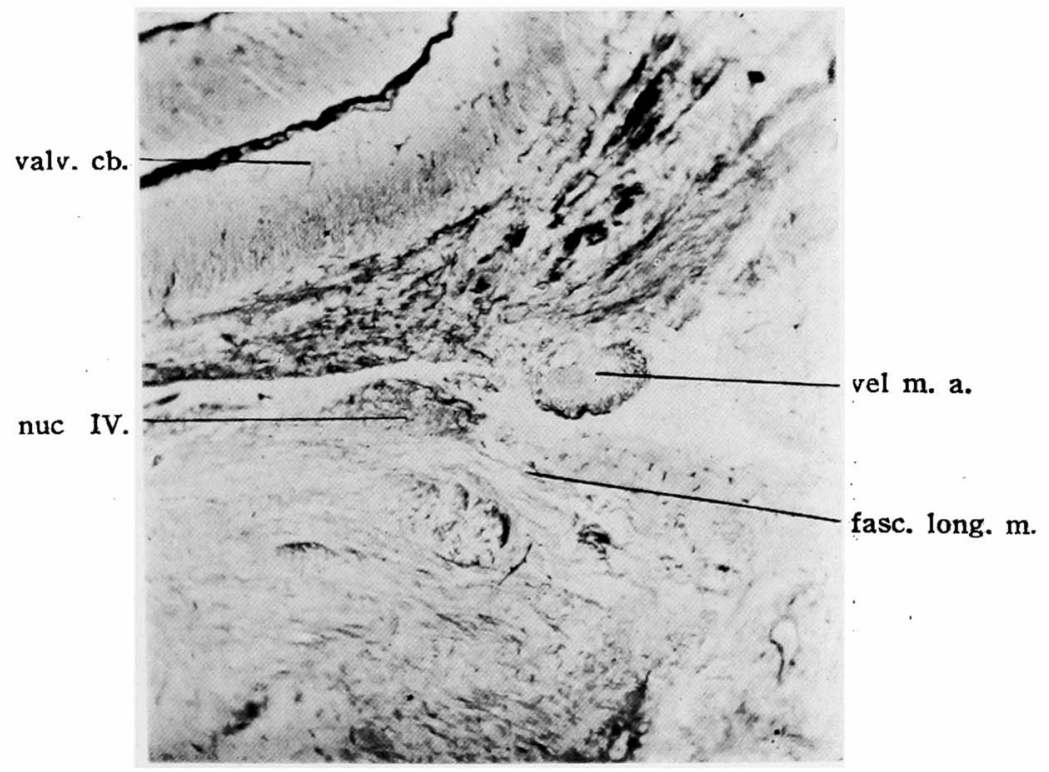

Fig. 6. Bagittal section passing through the nucleus trochlearis (Bielschowsky's pyridin silver method).

J. Tamura, K. Yashiki, K. Takata, and T. Yamao. 
Plate IV

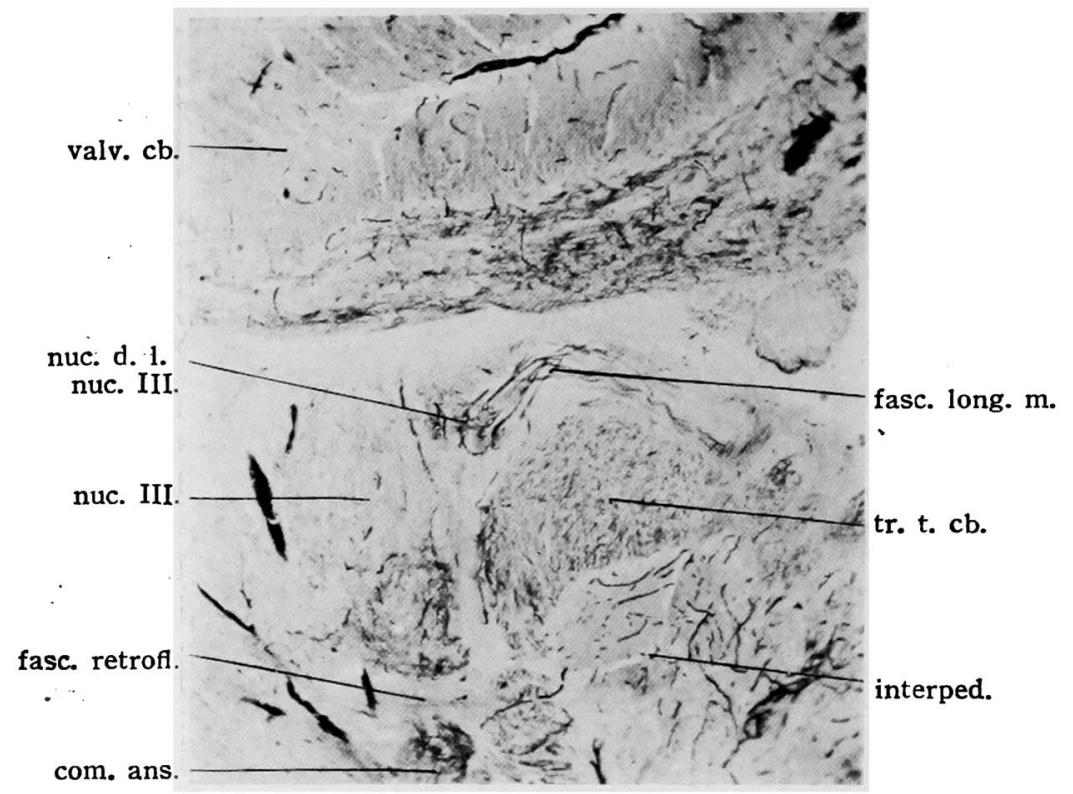

Fig. 7. Sagittal section passing through the nucleus oculomotorius (Bielschowsky's. pyridin silver method):

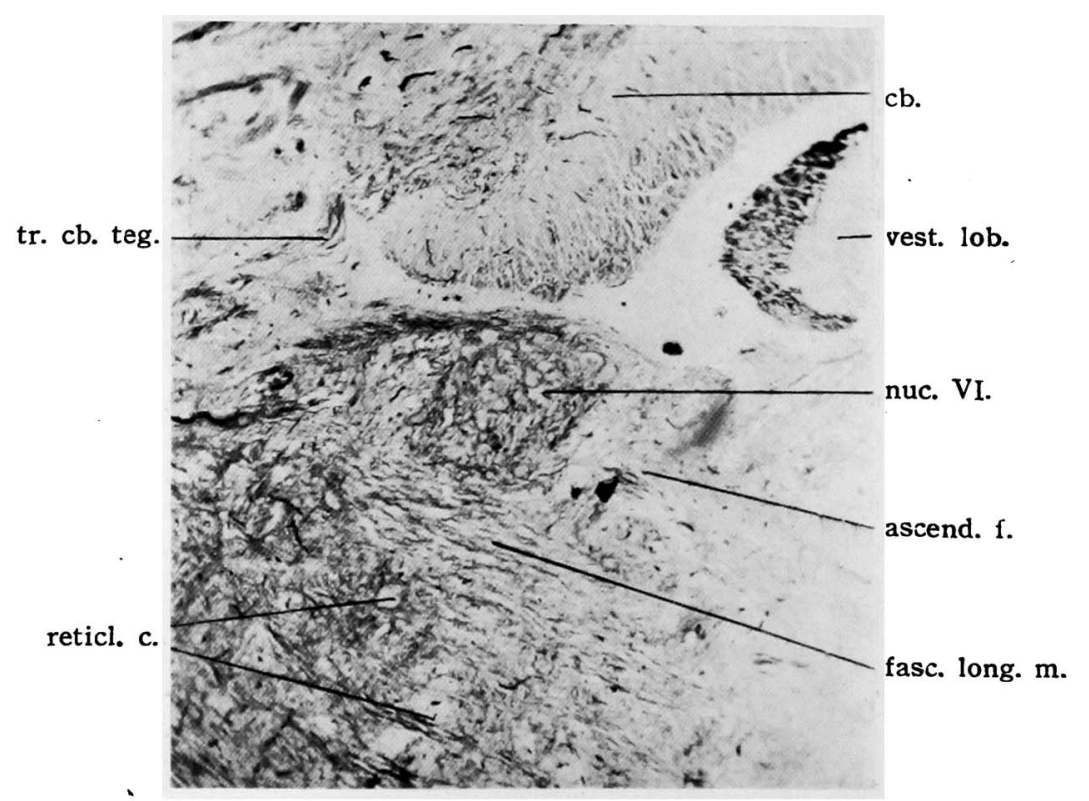

Fig. 8. Sagittal section passing through the nucleus abducens (Bielschowsky's pyridin silver method).

J. Tamura, K. Yashiki, K. Takata, and T. Yamao. 


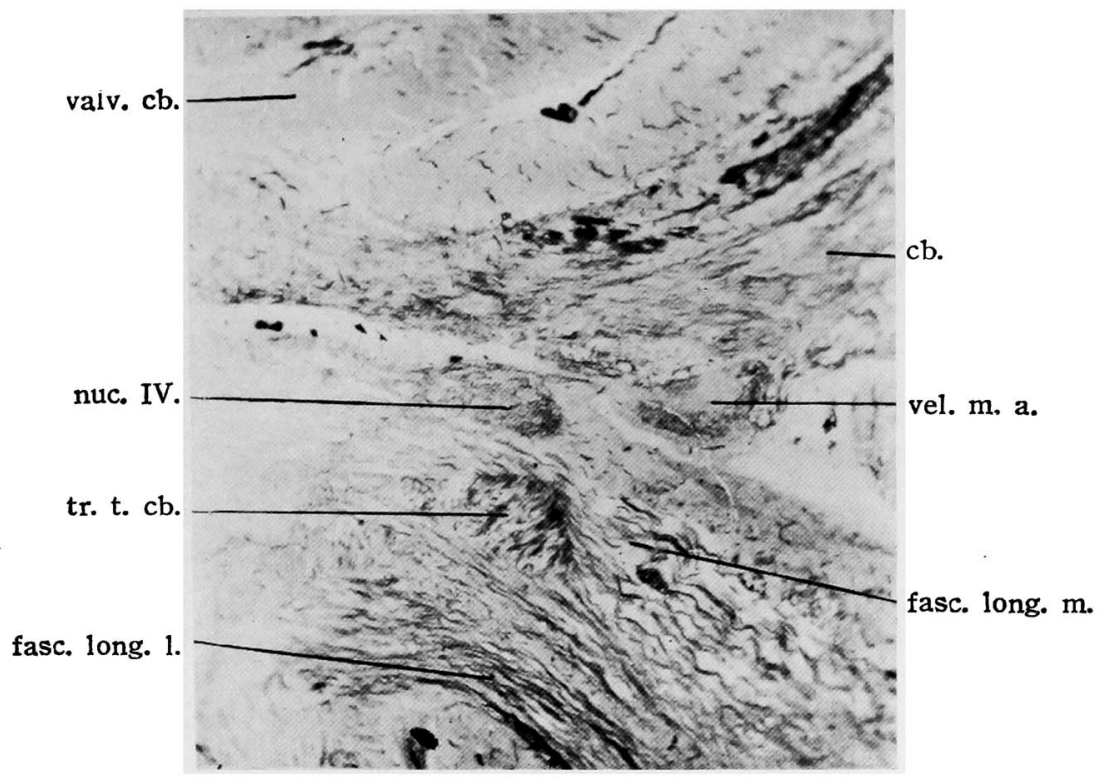

Fig. 9. Sagittal section passing through the nucleus trochlearis (Bielschowsky's pyridin silver method)

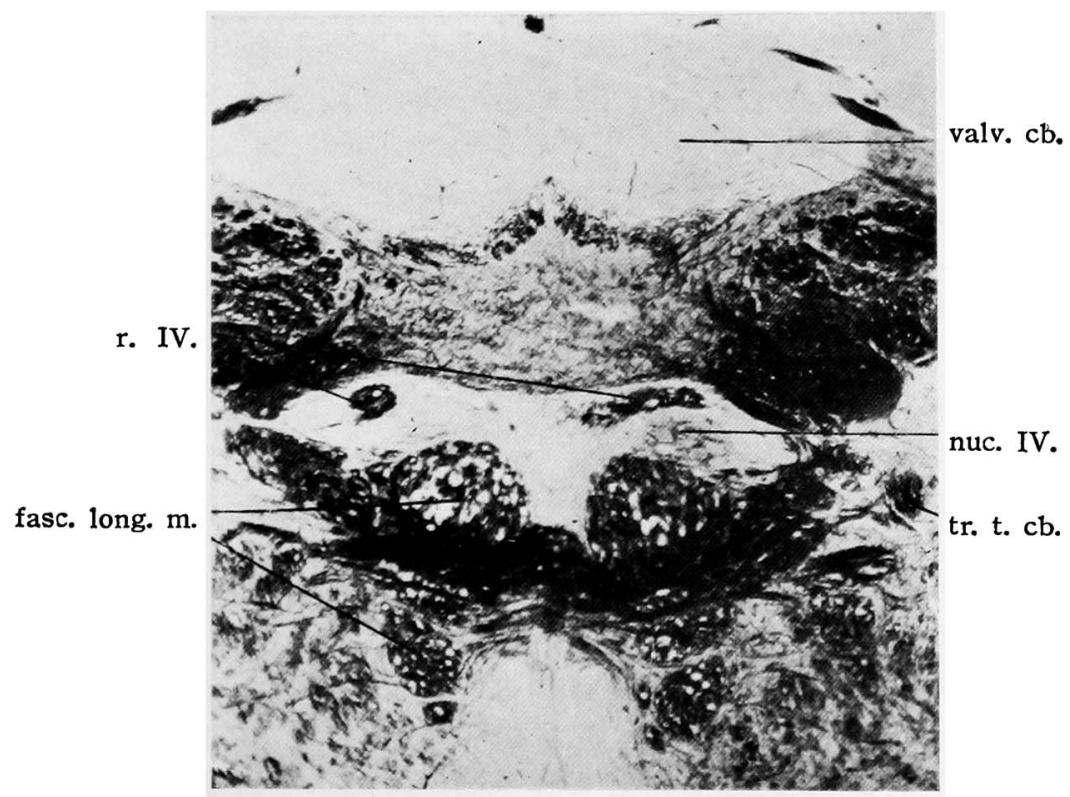

Fig. 10. Tarnsverse section passing through the nucleus trochlearis (Pal-carmine stained).

J. Tamura, K. Yashiki, K. Takata, and T. Yamao. 